\title{
Hiperplasia Adrenal Kongenital di Surabaya: Analisis Retrospektif Praktek Endokrin Anak 1997-2011
}

\author{
Connie Untario \\ Bagian Ilmu Kesehatan Anak RS Mitra Keluarga, Surabaya
}

\begin{abstract}
Latar belakang. Hiperplasia adrenal kongenital (HAK) merupakan suatu penyakit herediter yang mengakibatkan dampak sangat besar bagi pasien, keluarga dan lingkungannya namun masih sering terjadi keterlambatan diagnosis.

Tujuan. Melakukan analisis keluhan utama dan tanda awal HAK untuk membantu menegakkan diagnosis dini.

Metode. Analisis retrospektif kasus seri HAK pada praktek endokrin anak 1997-2011, pada 19 kasus, 10 perempuan dan 9 laki-laki. Semua kasus HAK dalam penelitian adalah pasien rujukan.

Hasil. Ambiguitas genitalia terdapat pada semua anak perempuan (10), 6 diantaranya sebagai keluhan utama. Tidak ada keluhan utama hiperpigmentasi walau didapatkan pada semua pasien kecuali 3 anak lakilaki. Seorang anak laki-laki datang dengan keluhan pubertas prekoks. Muntah dan diare ditemukan merata pada perempuan dan laki-laki (5:6). Pada seluruh anak laki-laki, muntah-diare merupakan keluhan utama, dan semua termasuk dalam kelompok salt wasting. Hanya didapatkan satu keluhan utama muntah-diare pada anak perempuan, 2 dari 7 pasien datang dengan keluhan utama gagal tumbuh. Tiga kasus didiagnosis berdasarkan riwayat keluarga. Terdapat 12 kasus didiagnosis sebelum berumur 1 bulan.

Kesimpulan. Sangat diperlukan kecermatan dalam melihat gejala klinis HAK. Ambiguitas genitalia pada perempuan, hiperpigmentasi kulit, muntah dan diare, serta gagal tumbuh adalah tanda-tanda klinis yang sangat penting. Pemeriksaan kadar natrium dan kalium sangat membantu sebelum dilakukan pemeriksaan hormon, karena berdasarkan temuan tersebut, penanganan kedaruratan gangguan elektrolit dapat segera diberikan. Melalui diagnosis dini kita dapat mencegah dampak buruk HAK seperti pemberian nama yang keliru, kegawatan karena gangguan elektrolit, bahkan krisis adrenal serta pubertas prekoks.
\end{abstract}

Sari Pediatri 2013;14(6):337-40.

Kata kunci: hiperplasia adrenal kongenital, ambiguitas genitalia, salt wasting

\footnotetext{
Alamat korespondensi:

Dr. Connie Untario, Sp.A. Jl. Kupang Indah No. 29, Surabaya 60225.

Telp.+6231-5682127. E-mail: connie.asrikin@gmail.com
}

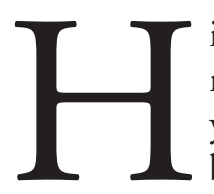

iperplasia adrenal kongenital (HAK) merupakan suatu penyakit herediter yang mengakibatkan dampak sangat besar bagi pasien, keluarga dan ling- 
kungannya. Namun, karena manifestasi gejala maupun derajat penyakit sangat bervariasi, maka seringkali terjadi keterlambatan atau salah diagnosis. Perbedaan manifestasi ini tergantung dari usia dan jenis kelamin pasien, serta derajat gangguan hormon yang terkait. Kadar hormon androgen yang tinggi mengakibatkan, terjadinya ambiguitas genitalia pada bayi perempuan. ${ }^{1,2}$ Pada bayi baru lahir, ambiguitas genitalia menjadi masalah besar karena penentuan jenis kelamin pada umumnya hanya berdasar pada fenotip bayi. Dengan pertambahan usia, ambiguitas genitalia akan makin menimbulkan beban psikologis bagi pasien dan keluarganya. Masalah lain yang mungkin menyusul pada beberapa minggu setelah kelahiran adalah kolaps kardiovaskular dan kehilangan garam karena produksi hormon glukokortikoid dan mineralokortikoid yang sangat kurang (salt-losing/ salt-wasting).

Keterlambatan dan kesalahan diagnosis hiperplasia adrenal kongenital pada bayi laki-laki lebih sering terjadi karena tidak ada tanda ambiguitas genitalia, yang pada bayi wanita dapat dipakai sebagai tanda diagnosis kemungkinan HAK. Pubertas prekoks yang terjadi pada anak laki-laki dapat merupakan suatu manifestasi HAK. Ancaman insufisiensi adrenal akut pada keadaan tertentu seperti sakit dan pembedahan merupakan beban lain yang harus dihadapi. Namun dengan penanganan yang tepat banyak kasus HAK berat yang dapat hidup dengan baik sampai usia tua. ${ }^{1,3,4}$ Ketelitian dalam menentukan jenis kelamin seorang bayi dan melakukan koreksi ambiguitas genitalia, kita dapat membantu menempatkan kembali pasien dalam kelompok gender yang benar. Pengenalan penyakit HAK lebih jauh maka akan banyak kasus yang dapat dideteksi secara dini dan mendapatkan terapi yang sesuai sehingga dampak yang lebih buruk dapat dihindarkan atau dikurangi. Pemantauan jangka panjang diperlukan untuk mencapai tumbuh kembang yang optimal, termasuk optimalisasi supresi hormon androgen dan optimalisasi fertilitas pada pasien wanita. Kepentingan lainnya adalah pada kehamilan berikutnya, melalui pemeriksaan dan pengobatan prenatal, ambiguitas genitalia pada anak perempuan dapat dicegah. ${ }^{5,6}$ Kasus seri yang kami sajikan menguraikan gambaran klinis awal pasien HAK, diharapkan dapat menggugah kewaspadaan para dokter terhadap kasus HAK.

\section{Metode}

Dilakukan analisis seri kasus yang didapat dari catatan medis semua pasien HAK di praktek swasta baik rawat inap maupun rawat jalan, sejak tahun 1997 sampai 2011. Kecurigaan diagnosis HAK berdasarkan pada riwayat HAK dalam keluarga, hiperpigmentasi, ambiguitas genitalia, muntah dan/atau diare yang sering disertai gagal tumbuh bayi pada awal kehidupan, pubertas prekoks serta terjadinya krisis adrenal. Diagnosis HAK ditegakkan berdasarkan pada gejala klinis pasien dan hasil pemeriksaan laboratorium yaitu adanya kelebihan hormon androgen, kekurangan hormon glukokortikoid dan/atau mineralokortikoid. Dalam hal ini tidak dilakukan uji stimulasi ACTH. Sedangkan diagnosis defisiensi 21-OH dehidrogenase (21-OHD) berdasarkan pada peningkatan kadar 17-OHP. Pasien dengan kadar Natrium $<135$ $\mathrm{mmol} / \mathrm{L}$ dan/atau kadar Kalium serum $>5,5 \mathrm{mmol} / \mathrm{L}$ dimasukkan dalam kelompok salt-wasting type. Semua pemeriksaan laboratorium awal dilakukan sebelum pengobatan hormon, kecuali untuk pasien krisis adrenal. Kariotiping diperiksa untuk penentuan jenis kelamin. Pemeriksaan laboratorium untuk 17-OHP dilakukan tergantung pada kemampuan ekonomi pasien. Pemeriksaan fisik dan genitalia eksterna dilakukan pada semua pasien saat diagnosis dan pada waktu kontrol. Setiap pasien dicatat dengan keluhan utama dan tanda-tanda lain yang ditemukan serta umur saat diagnosis. Diagnosis dianggap terlambat apabila umur saat diagnosis lebih dari satu bulan, sedangkan gagal tumbuh apabila terjadi perlambatan kecepatan tumbuh yang mengakibatkan garis pertumbuhan memotong dua garis persentil di bawahnya pada kurva pertumbuhan anak. ${ }^{7}$

\section{Hasil}

Selama lima tahun pengamatan dijumpai 19 pasien HAK, Terdiri dari 10 anak perempuan dan 9 anak laki-laki. Menurut etnis dan ras, 12 bayi berasal dari etnis Jawa dan 7 bayi etnis Tionghoa. Gejala dan kelainan yang tampak sebelum usia 30 hari didapatkan pada 12 pasien. Ambiguitas genitalia didapatkan pada semua pasien perempuan sejak lahir, tiga orang anak di antaranya terlanjur diberi nama laki-laki. Hiperpigmentasi didapatkan pada semua pasien, kecuali tiga pasien laki-laki yaitu satu bayi dan dua 
Tabel 1. Rekapitulasi gambaran klinis diagnosis HAK ditegakkan pada 10 anak perempuan

\begin{tabular}{|c|c|c|c|c|c|c|c|c|c|c|c|c|}
\hline \multirow{2}{*}{ Gambaran klinis } & \multicolumn{11}{|c|}{ Umur saat diagnosis } & \multirow{2}{*}{ - Keterangan } \\
\hline & $1 \mathrm{bl}$ & $2 \mathrm{mg}$ & 9 th & $1 \mathrm{mg}$ & $3 \mathrm{bl}$ & $1 \mathrm{bl}$ & $1 \mathrm{bl}$ & $1 \mathrm{bl}$ & $2 \mathrm{bl}$ & $2 \mathrm{mg}$ & & \\
\hline Ambiguitas genitalia & + & + & + & + & + & + & + & + & + & + & + & keluhan utama $(6 / 10)$ \\
\hline Pigmentasi kulit & + & + & + & + & + & + & + & + & + & + & & \\
\hline Pubertas prekoks & * & - & - & - & - & - & - & $*$ & - & - & & * terjadi pada usia anak-anak \\
\hline Muntah diare & + & - & - & + & + & + & + & - & - & - & + & keluhan utama $(1 / 10)$ \\
\hline Gagal tumbuh & + & - & - & - & + & + & - & - & - & - & + & keluhan utama $(2 / 10)$ \\
\hline Riwayat keluarga & - & - & - & + & - & - & - & - & - & - & + & keluhan utama $(1 / 10)$ \\
\hline Salt-wasting & - & + & - & + & - & + & + & - & - & - & & \\
\hline Krisis adrenal & - & - & - & - & - & - & - & - & - & - & & \\
\hline
\end{tabular}

Tabel 2. Rekapitulasi gambaran klinis diagnosis HAK ditegakkan pada 9 anak laki-laki

\begin{tabular}{lcccccccccc}
\hline \multirow{2}{*}{ Gambaran klinis } & \multicolumn{10}{c}{ Umur saat diagnosis } \\
\cline { 2 - 9 } & $2 \mathrm{bl}$ & $1 \mathrm{bl}$ & $1 \mathrm{mg}$ & $1 \mathrm{bl}$ & $2 \mathrm{mg}$ & $1 \mathrm{mg}$ & 10 th $7 \mathrm{bl}$ & 2 th $3 \mathrm{bl}$ & $2 \mathrm{bl}$ & Keterangan \\
\hline Ambiguitas genitalia & - & - & - & - & - & - & - & - & - & \\
Pigmentasi kulit & + & + & + & + & - & + & - & - & + & \\
Pubertas prekoks & - & - & - & - & - & - & + & - & - & + \\
Muntah diare & + & + & + & + & + & - & - & - & + & + \\
Gagal tumbun utama $(1 / 9)$ \\
Riwayat keluarga & + & + & - & + & - & - & - & - & + & \\
Salt-wasting & - & - & - & - & - & + & - & + & - & + \\
Krisis adrenal & + & + & + & + & + & - & - & - & + & \\
\hline
\end{tabular}

anak. Kedua anak tersebut kakak-beradik, kakaknya mengalami pubertas prekoks sehingga adiknya turut diperiksa. Pemeriksaan fisik dan laboratorium berdasarkan riwayat HAK dalam keluarga dilakukan pada tiga orang pasien. Pubertas prekoks pada saat diagnosa hanya didapatkan pada satu pasien laki-laki. Sedangkan 2 anak perempuan yang didiagnosis pada saat bayi mengalami pubertas prekoks saat berusia 7 dan 7.5 tahun. Dari seluruh pasien, didapatkan 10 orang anak yang mengalami salt-wasting, 4 perempuan dan 6 laki-laki. Dari anamnesis, pada semua kasus tidak didapatkan adanya hubungan darah antara ayah dan ibu. Muntah dan diare didapatkan pada 11 pasien, dua di antaranya tidak menunjukkan gejala salt-wasting. Kadar rerata hiponatremia $117,6 \mathrm{mEq} / \mathrm{L}$ dengan rentang $108-132 \mathrm{mEq} / \mathrm{L}$ dan kadar rerata hiperkalemia $7,98 \mathrm{mEq} / \mathrm{L}$ dengan rentang $5-10,5 \mathrm{mEq} / \mathrm{L}$. Satu pasien kelompok salt-wasting dengan kadar Natrium yang rendah yaitu $121 \mathrm{mEq} / \mathrm{L}$, menunjukkan kadar Kalium $5 \mathrm{mEq} / \mathrm{L}$. Hanya satu bayi laki-laki yang dilakukan pemeriksaan analisis DNA yaitu gen CYP21, hasilnya menunjukkan homozygous for the intron 2 mutation. Satu pasien perempuan datang pada usia 9 tahun dengan ambiguitas genitalia, klitoromegali, hiperpigmentasi hebat. Pasien tersebut menderita tumor ovarium dan dilakukan operasi. Adrenal krisis sebagai tanda awal kecurigaan akan HAK didapatkan pada 1 pasien.

\section{Pembahasan}

Pada bayi perempuan dengan HAK didapatkan tanda ambiguitas genitalia, maka kecurigaan akan HAK lebih cepat diketahui dibandingkan bayi laki-laki. Namun, dalam seri kasus yang ditampilkan masih tampak keterlambatan. Ditemukan 12 pasien HAK sebelum usia satu bulan, sisanya diagnosis ditegakkan pada usia lebih dari satu bulan. Bahkan, satu pasien perempuan baru didiagnosis HAK pada usia 9 tahun walaupun menunjukkan ambiguitas genitalia, karena pasien tidak mendapatkan penanganan yang adekuat dari dokter yang pernah merawatnya. Hiperpigmentasi terdapat pada hampir semua pasien. Tanda klinis 
tersebut merupakan satu tanda yang dapat dipakai untuk memperkuat kecurigaan diagnosis HAK. ${ }^{6,8}$ Tidak satupun pasien datang dengan keluhan utama hiperpigmentasi. Pada umumnya, orang tua menganggap hal tersebut normal dan bukan merupakan tanda penyakit. Diagnosis bayi dengan salt-wasting lebih cepat ditegakkan karena terjadi gejala muntah pada minggu pertama kehidupan. Ambiguitas genitalia yang sangat membantu penegakkan diagnosis bayi perempuan, tidak terjadi pada bayi laki-laki. Oleh karena itu, pada HAK bayi laki-laki, salt-wasting, yang sering dimanifestasikan dengan muntah-diare sangat membantu penegakan diagnosis. Dari sebelas pasien yang mengalami muntah dan diare, delapan diantaranya terdiagnosis HAK sebelum usia 30 hari dan tiga pasien setelahnya. Selain salt-wasting, seperti yang terjadi pada penelitian kami, riwayat keluarga juga dapat digunakan untuk penemuan kasus. Pasien tanpa gejala salt-wasting, gejala pubertas prekoks sering menjadi tanda awal. ${ }^{1,2,9}$ Kami mendapatkan 10 pasien perempuan, semua mempunyai tanda ambiguitas genitalia, tetapi hanya enam di antaranya yang datang dengan keluhan utama tanda klinis tersebut. Temuan ini menunjukkan tingkat kesadaran yang masih rendah betapa penting penentuan jenis kelamin seorang bayi dengan benar. Tidak didapatkan orangtua yang mempunyai hubungan darah antara ayah dan ibu, walaupun demikian hubungan darah antara tersebut tetap harus ditanyakan. Frekuensi mutasi pada populasi umum diperkirakan dijumpai pada 1 dari 60 penduduk. Apabila kedua orang tua pembawa, maka $25 \%$ anaknya akan memiliki kesempatan terjadi mutan. ${ }^{10}$

\section{Kesimpulan}

Mengingat tidak ada skrining HAK pada bayi baru lahir, maka sangat diperlukan kecermatan dalam mencari gejala klinis awal pada pemeriksaan awal kehidupan. Ambiguitas genitalia pada perempuan, hiperpigmentasi kulit, muntah dan diare, serta gagal tumbuh, adalah tanda-tanda klinis yang sangat penting untuk diperhatikan pada bayi dengan HAK. Hasil laboratorium hiponatremia dan hiperkalemia sangat membantu untuk pusat kesehatan yang tidak dilengkapi dengan pemeriksaan hormon. Berdasarkan temuan pemeriksaan laboratorium tersebut, penanganan kedaruratan gangguan elektrolit dapat segera diberikan. Penegakan diagnosis dini dapat mencegah dampak HAK yang buruk seperti pemberian nama yang keliru, kegawatan karena gangguan elektrolit, bahkan krisis adrenal serta pubertas prekoks.

\section{Daftar pustaka}

1. Huma Z, Crawford C, New MI. Congenital adrenal hyperplasia. Dalam: Brook CGD, penyunting. Clinical paediatric endocrinology. Oxford: Blackwell Science; 1995.h. 536-57.

2. Witchel SF, Azziz R. Congenital adrenal hyperplasia. J Pediatric and Adolescent Gynecol. 2011;24:116-26.

3. Zachmann M, Prader A. The adrenogenital syndrome. Dalam: Labhart A, penyunting. Clinical endocrinologytheory and practice. Berlin: Springer-Verlag; 1986.h.42537.

4. Speiser PW, White PC. Congenital adrenal hyperplasia due to steroid 21-hydroxylase deficiency. J Clin Endocrinol 1998;49:411-7.

5. Wales JKH, Rogol AD, Wit JM. Color atlas of paediatric endocrinology and growth. London: Mosby-Wolfe; 1996.h.107-8.

6. Demirci C, Witchel SF. Congenital adrenal hyperplasia. Dermatologic Therapy 2008;21:340-53.

7. Irwanto, Suryawan A, Narendra MB. Penyimpangan tumbuh kembang Anak. continuing education: Ilmu Kesehatan Anak XXXVI; Surabaya: 29-30 Juli 2006.

8. Miller WL. Brook's Clinical Pediatric Endocrinology. The adrenal cortex and its disorders. Edisi ke-4. Oxford: Blackwell Science; 2001.h.338-52.

9. Trakakis E, Basios G, Trompoukis P, Labos G, Grammatikakis I, Kassanos D. An update to 21-hydroxylase deficient congenital adrenal hyperplasia. The Int Soc of Gynec Endocrinol. 2010;26:63-71.

10. Susanto R. Hiperplasia adrenal kongenital: aspek genetik. The Indonesian course in genetic counseling; Semarang: 15-18 Januari 2003. 